\title{
Guarding the Gates of St Peter: life, death and law making
}

Jonathan Montgomery, Professor of Health Care Law, University of Southampton ${ }^{1}$

This is the peer reviewed version of the following article: 'Guarding the gates of St Peter: life, death and law making' (2011) 31(4) Legal Studies 644-666, which has been published in final form at DOI: 10.1111/j.1748-121X.2011.00205.x. This article may be used for non-commercial purposes in accordance With Wiley Terms and Conditions for selfarchiving.

\section{Abstract}

In 2009 the legislature, judges and Director of Public Prosecutions each turned their attention to issues around assisted suicide. The legislature decided not to change the law. The judges decided the existing law was insufficiently clear and required to the Director to clarify it. The Director flirted with reforming the law, but then drew back from such a legislative role. His published prosecution policy has been considered as a contribution to the regulation of death and dying, and as such has been found wanting. However, considered in the context of the proper roles of Parliament, courts and prosecutors, and seen as an exercise in constitutional restraint, the Director's approach should be appraised rather differently. From this perspective, the decision of the Judicial

\footnotetext{
${ }^{1}$ This paper is a development of the Bailiff's Lecture, delivered on 21 October 2009 in St Peters Port, Guernsey. I am grateful to the Bailiff, Sir Geoffrey Rowland, and members of the audience for their comments and questions on the thesis put forward, which has been revised in the light of their feedback. I am also grateful for the Legal Studies reviewer's comments, which led to further improvements. The imperfections that remain are my responsibility.
} 


\section{Committee of the House of Lords raises significant concerns for the legitimacy of decision making in the contested moral issues that arise in health care ethics. In our democracy, courts should be wary of usurping legislative authority in areas where the Parliamentary position is clear. They should be reluctant to take sides in the protracted war over access to a 'good death'.}

\section{Introduction}

In 1630, John Donne (the great poet and celebrated Anglican 'divine') preached a famous sermon in Whitehall known as Death's Duel. It was the last sermon he gave before he died and it is widely regarded as his meditation on his own impending death. This seems an appropriate place to begin an examination of the current legal controversies over dying. Although the text is a religious one, Donne's wider concerns show a number of resonances with our theme. He was in fact a reluctant priest, having first practised law. In 1608, he wrote a pamphlet exploring the argument that suicide was not necessarily a sin (published only posthumously in 1644). He also served briefly as a Member of Parliament and so had a legislative role.

Donne presented three senses in which God gave 'deliverance' in the context of the duel with death. First, deliverance 'from death', which could be seen as the traditional preserve of medicine of preventing unnecessary deaths. Second, deliverance 'in death', by which God took care of us in the hour of death. Third, deliverance 'by death' - a theological account of the Christian doctrine of eternal salvation through the death of Jesus. For the purposes of this paper, we can leave the first sense of deliverance for the doctors and the third sense for the theologians. Our interest is in the second area of Donne's concerns - deliverance in the process of dying and the role of lawyers in responding to it.

The summer of 2009 saw three significant explorations of the issues in the United Kingdom. On $7^{\text {th }}$ July, legislators in the House of Lords considered an amendment to the Coroners and Justice Bill 2009 that sought to provide protection for people travelling to Switzerland to take advantage of the fact that assisted suicide is permissible in parts of that country. ${ }^{2}$ At the end of the same month, the Judicial Committee of the House of Lords, in the very last of its decisions before the appellate responsibilities transferred to the new Supreme Court, delivered the opinions on Debbie Purdy's challenge to the law on assisted suicide in England and Wales. ${ }^{3}$ As a result of the requirement in that case for a clarification of the basis on which prosecution decisions would be taken, a third event followed - the publication on September 232009 of the interim statement on the factors to be taken into account by Keir Starmer QC, the Director of Public Prosecutions, finalised after a consultation period which ran until the middle of December 2009. The

\footnotetext{
${ }^{2}$ HL Debates, Amendment 173, Hansard 7 July 2009, Cols 595-636.
}

${ }^{3} R$ (Purdy) v DPP [2009] UKHL 45. 
resulting policy, which contained some significant differences to the interim statement, ${ }^{4}$ was issued in February 2010 and has already been applied in a number of cases in which the decision has been made public via the Crown Prosecution Society's website.

This paper reflects on the issues raised by these events for constitutional theory in particular, the roles that are appropriate for courts and those who administer the law (in this case prosecutors) in the face of contested moral issues. It is not concerned with the rights and wrongs of assisted suicide, but with the channels through which the debates over the substance of the law should properly be pursued in a liberal democratic society. It uses a brief survey of developments in other jurisdictions to show how countries across the world are struggling with the issues and that suggestions that there is a uniform direction of travel are overstated. This suggests that democratic debate should be open on these issues, rather than closed down by the courts stretching legal doctrines into territory for which they were not designed.

The concerns raised by Penney Lewis over the absence of public and parliamentary debate and scrutiny of the Director's approach, and the poverty of the 'quantitative and secretive approach to the public consultation' shed an important light on these issues. ${ }^{5}$ However, this piece draws a rather different conclusion on the Director's contribution. It argues that the prosecution policy that was ultimately issued is best understood as deriving from an acceptance of the proper constitutional position of the prosecutor, and as an act of resistance to a misguided invitation from the judicial committee of the House of Lords to make an inappropriate legislative contribution to an issue on which Parliament's position is clear. If this analysis is correct, seeing the new policy as addressing 'dangers' and 'implicitly describing... a class of assisted suicides which are permissible' is not the best explanation of what he has set out to do. ${ }^{6}$ While these observations were fairly made of the interim policy, it will be argued that the final policy is best interpreted as drawing back from the brink of such a quasi-legislative intervention and declining to play a role in the clash of moralities that lies behind the Parliamentary proposals for law reform and the litigation in Purdy.

The metaphor of the duel developed by John Donne seems particularly apposite for this chain of events; through it we are seeing a series of skirmishes in the long running guerilla war over how access to death should be regulated. It is fought between those who see the issues as a straightforward matter of individual freedom, in which wider considerations of social value are less important than the choices available to individual citizens, and those who see it as an issue about the position that society should take on the value and dignity of human life. The latter view sees these concerns as independent of matters of individual freedom because they concern precisely the values that underpin all our freedoms. To compromise them in the interests of individual choice would be to undermine the foundation of freedom for others. The former view sees the availability of choice as the very essence of those freedoms, so that compromising it would be self-defeating. These positions are not easily reconcilable and the tension manifests itself in many ways and places. Although the particular context of this paper is

\footnotetext{
${ }^{4}$ For a detailed analysis of the differences, see P Lewis, 'Informal legal change on assisted suicide: the policy for prosecutors’ (2010) Legal Studies DOI:10.1111/j.1748-121X.2010.00184x.

${ }^{5}$ Ibid. at $\mathrm{p} 15$.

${ }^{6}$ These phrases are also taken from the conclusion to Lewis's article, p 15.
} 
the duel of 2009 fought out in London (and its direct consequences), it can be seen across Europe and the common law world.

There are those who see this as a war of attrition, by which a traditional (and they might say outdated) approach to the sanctity of human life is being gradually supplanted by a commitment to individual autonomy that overrides all other concerns. They see the long-term trajectory as the inevitable victory of the pro-autonomy army and the resistance as a doomed rearguard action. From the perspective of those who deplore the change, the challenge is seen through the metaphor of the slippery slope - each step towards so-called liberalization needs to be contested to prevent the slide towards an amoral society in which choice is valued at the expense of moral principle, human dignity and the protection of vulnerable members of our communities.

It is therefore clear that these three specific legal events, a legislative vote, a judicial decision, and an administrative policy need to be placed in the context of this debate about our understanding of death and dying. Their coincidence also enables us to address some difficult questions about the role of law and lawyers in the debate. How do the responsibilities of legislators, judges and law officers differ in this area of law? At what level should which decisions be taken? How are the constitutional limits on the three arms of government to be interpreted? Answering these questions will enable us to consider whether the keys to the gates of St Peter, the route into heaven, are in good hands. We also need to consider the interplay of general constitutional principles with the specific characteristics of the health care context in which the issues have arisen. The medicalization of death and dying plays an important contextual role to the debates, colouring the legal solutions adopted. ${ }^{7}$ There may be a particular constitutional settlement around the degree of clinical freedom that we are prepared to permit doctors, which also needs to be taken into account. ${ }^{8}$

\section{In whom do we trust?}

In one sense, this is familiar territory and one that has been addressed across the globe over the past few years. Even a small legal jurisdiction such as Guernsey has given it careful consideration (in 2004) and the issue remains live; even though it is hard to suggest that the fundamental issues have changed, the question continues to be raised although proposals that it should be revisited at again have been resisted. ${ }^{9}$ Nevertheless, although the issues may be familiar, the nature of the legal responses and the terms on which the discussion is framed are perhaps changing. This paper argues that those events in London in 2009 demonstrate that the judiciary has stepped beyond the territory that is appropriate for the courts into the province of the legislature. Although this has been done in the name of human rights, it suggests that it is not in fact a necessary

\footnotetext{
${ }^{7}$ See for explorations of this point, S Ost, 'The De-Medicalisation of Assisted Dying: Is a Less Medicalised Model the Way Forward?' (2010) 18 Med Law Rev 497- 540; J Coggon, 'Assisted Dying and the Context of Debate: 'Medical Law' Versus 'End-Of-Life Law' (2010) 18 Med Law Rev 541-563.

${ }^{8}$ See more generally on this point, J. Montgomery, 'The virtues and vices of professionalism' in D Bhugra and A Malik (eds) Professionalism in Mental Healthcare, (Cambridge: Cambridge University Press, 2011), $17-31$.

${ }^{9}$ Guernsey Press 19 March 2009.
} 
consequence of the legal version of those rights set out in the European Convention, contrary to the analysis of Article 8 given by the House of Lords. It contends that Article 8 's protection of our privacy - requiring respect for private and family life, but defined since Pretty $v U K^{10}$ as including autonomy - has been stretched to allow judicial legislation in a way avoided by the European Court of Human Rights in that case. This illustrates a wider concern about the legitimacy of democratic decision making being supplanted by a form of legalism, which although superficially attractive, should not be permitted to supplant wider social debate. ${ }^{11}$

The current legal position in England and Wales over medical access to death can be characterised quite briefly, but sufficiently to provide the context for the exploration of these issues. First, the principles governing active euthanasia - the ending of a life in order to secure a 'good death'. Initially established in a celebrated murder trial in 1957 , the Bodkin Adams case, the position seems clear. It is not permissible to take steps to end the lives of your patients. That remains murder and doctors are given no licence to commit murder. However, accommodations have been reached in a number of respects to reflect the recognition that medicine is an uncertain art that cannot always succeed in preserving life. The law has accepted that when it cannot preserve life there are other purposes to which the doctors' skills should be put. Most explicitly, the courts have accepted that in some cases doctors may use drugs to relieve pain even when they know that there is a risk that death may come earlier through their use. This 'defence' may be made out where three conditions are met; the patient is dying, the care offered is medically appropriate - 'right and proper treatment' - and where the primary purpose is to relieve pain not cause death. ${ }^{12}$

Although now well established, albeit on the technically flimsy authority of jury directions rather than the consideration of an appellate court, the three components sit uneasily with general principles of criminal law. The proximity of death from another cause is usually no excuse for murder. The fact that a profession regards something as appropriate does not usually justify overriding a criminal prohibition (although some crimes are defined by reference to industry practice). The law usually denies the relevance of motive to guilt (as opposed to mitigation of sentence), preferring to

\footnotetext{
${ }^{10}$ [2002] 2 FCR 97.

${ }^{11}$ For further discussion on this point, see J Montgomery, 'The Legitimacy of Medical Law' In McLean, S (ed) First do no harm: Law, ethics and healthcare (Aldershot: Ashgate, 2006), 1-16

${ }^{12} R v$ Adams [1957] Crim LR 365.
} 
concentrate on intention. ${ }^{13}$ Nevertheless, recognition of the importance of deliverance in dying has led to a relaxation of the sharpness of the law of murder. ${ }^{14}$

If the legal principles applied to active euthanasia need to be derived from relatively light legal authorities, the same cannot be said of the law relating to so-called 'passive euthanasia' - the withdrawing or withholding of treatment that might prolong life. Passive euthanasia is characterised by some as allowing people to die, or 'letting nature take its course', rather than causing death. Yet it is one of the roles of health professionals to prevent nature taking its course - after all that is precisely what antibiotics are designed to do - and we routinely expect doctors to intervene to save life. When asked to rule on the issues in the case of Tony Bland, a young man crushed in the Hillsborough Stadium disaster who never regained consciousness, the House of Lords had to consider the scope of the legal duty of health professionals to keep patients alive. ${ }^{15}$ Although there is room for considerable debate about the precise basis of their conclusion, ${ }^{16}$ the House held that the duty should be defined by reference to 'responsible medical practice' in assessing what was in the patient's best interests.

Thus, there is a clear rule against killing, upholding the principle that life is precious, but its application is mitigated by flexibility drawing on good professional practice as a guide. There is also recognition that there is more to good medicine than merely fighting off death - the deliverance from death of Donne's tripartite typology - so that it is accepted that responsible doctors may properly move from a curative to a palliative paradigm for patients under their care. Limiting efforts to keep people alive in their wider best interests can be acceptable if it is responsible medical practice. In the cases of both active and passive euthanasia, the application of the law to the specific circumstances in which a patient finds themselves is mediated through the filter of professional discretion. This is judged in the light of peer review (the Bolam test practices accepted as proper by a responsible body of medical men skilled in that particular art) ${ }^{17}$ when called into question before the courts, allowing for flexibility and understanding of the circumstances of the case. Thus, it could be said, the keys to the gates of St Peter are entrusted by the law to the hands of the medical profession.

\footnotetext{
${ }^{13}$ Alan Norrie has observed that this orthodox position is closely connected to the prioritisation of social order over individual need and has traced its origins in the protection private property. He argues that the exclusion of a 'morally more serious definition of culpability' (in which motive is taken into account) follows from the law's adoption of a 'particular, but contestable moral view of the just social order'. Consequently, the concentration on intention and the exclusion of motive 'masks' the particular moral and political content of the law. See A Norrie, Crime, Reason and History: a critical introduction to criminal law (London: Butterworths, $2^{\text {nd }}$ ed 2001) at pp 35-46, 226-7. The adaption of the principle that motive should be excluded in the context of medical assistance in dying may be seen as a recognition that the special trust placed in doctors is part of the social order to be protected. I am grateful to the anonymous reviewer who suggested pointed out the relevance of this work, which opens up an important line of enquiry to which justice cannot be done here.

${ }^{14}$ For Norrie's discussion of further adaptations of the concept of intention to accommodate medical practice in Gillick $v$ W Norfolk \& Wisbech AHA [1985] 3 All ER 402, Airedale NHS Trust v Bland [1993] 1 All ER 821, and $R v$ Moor [2000] Crim LR 31, 566, see op. cit p 40.

${ }^{15}$ Airedale NHS Trust $v$ Bland [1993] 1 All ER 821.

${ }^{16}$ See J Montgomery, Health Care Law (Oxford: Oxford University Press 2003) ch 20 for a discussion of the issues.

${ }^{17}$ Bolam v. Friern HMC [1957] 2 All ER 118, 121.
} 
This was confirmed by the Court of Appeal in 2005 in the case of Burke $v$ GMC. ${ }^{18}$ Leslie Burke, who was disabled through motor neurone disease, challenged guidance from the General Medical Council on the basis that it failed to guarantee him food and water at the end of his life because there was a medical discretion to withhold care when it was thought by the clinicians to be appropriate to do so. The GMC accepted that it was highly likely that Burke would in fact have received the care that he wished when his health deteriorated. However, they took the case to appeal to secure the confirmation of the court of the need to protect professional discretion, rather than allow the law to provide patients with rights to dictate the care that they receive even where doctors thought the treatment would be inappropriate. Once again, the legal guardian of the gate to life sustaining treatment was confirmed as the doctor not the patient.

\section{Going Dutch?}

While this trust in doctors is a characteristic of English health care law, it is not of course universal and other countries have chosen to regulate the management of death and dying differently. ${ }^{19}$ There is much interest in the Dutch approach, which grew out of prosecution policy, was driven by the codification of medical practice, and then eventually became enshrined in legislation. This historical development is extremely illuminating. Holland did not initially legalize euthanasia, but rather established out a set of procedures, which if followed, would provide doctors from immunity from prosecution. It therefore maintained for some time a strong legislative commitment to the value of life, while enabling its relaxation in individual cases. This contrast between the explicit statement of the value of life and the mitigation of the impact of that position on particular patients suffering at the end of their lives is in itself an interesting aspect of the dilemma facing legislators.

One account of the role of the law in these sensitive areas stresses the way in which the legal rules express the values of society. ${ }^{20}$ This aspect of legal regulation supports contentions that euthanasia may be discriminatory because it projects the view that some lives, particularly those of disabilities, are less valuable than others. Thus, in its response to the DPP's consultation on the prosecution policy, the Equality and Human Rights Commission wrote

Our primary concern about the interim guidance is that the criterion relating to the physical condition of the victim has been too widely drawn.... To include 'having a severe and incurable physical disability, or a severe degenerative physical condition' suggests that the life of a disabled person who is not terminally ill is worth less than the life of a person who is not disabled. ${ }^{21}$

\footnotetext{
${ }^{18} R$ (Burke) v GMC [2005] EWCA Civ 1003.

${ }^{19}$ See e.g. P Lewis, Assisted Dying and Legal Change (Oxford: Oxford University Press 2007) and M Otlowski, Voluntary Euthanasia and the Common Law (Oxford: Oxford University Press 1997).

${ }^{20}$ Mary Ann Glendon, Abortion and Divorce in Western Law (Harvard University Press 1989).

${ }^{21}$ Equality and Human Rights Commission response to DPP's Consultation on Assisted Suicide, para 17. (Available at http://www.equalityhumanrights.com/uploaded_files/consultations/dpp_consultation_on_assisted_suicide_ ehrc_response_final_december_09.doc, last accessed 30 October 2010.)
} 
This understanding of the significance of substantive legal provisions in projecting social values can also be deployed to explain the apparent contradictions in a non-prosecution policy. Maintaining a legal prohibition of euthanasia makes a legislative commitment that expresses society's acceptance of the value of life. Permitting relaxation in specific cases may serve to achieve both the expression of the value of life and also the recognition that it may be harsh to visit the consequences of that expression on individuals who believe that their time has come to die. However, there is an equilibrium to be maintained if this account is to be coherent. If the scope for relaxation is too narrow, individuals are being sacrificed on the altar of principle. If the scope is too wide, then the legal principles are being rewritten surreptitiously through the prosecution policy.

It was precisely this balance that the House of Lords called into question in Purdy. Its chance to do so was created by the challenge brought to the prosecution policy in a way that seems to play a similar strategic role in the duel over death and dying to the way in which Holland's approach to Euthanasia unfolded. Essentially, the Dutch developments reduced the doctors' exposure to the risk of litigation by establishing (through test cases) principles to guide their practice which would reduce the likelihood of prosecution. This was established despite the fact that the conduct in question crossed the legal boundary that defined the difference between lawful and criminal behaviour. Only in 2002, twenty years after the actions that led to the Supreme Court decision in Schoonheim, ${ }^{22}$ was the threat of prosecution finally lifted by amending the criminal code to make the practice of euthanasia lawful. Until that time, doctors relied on the consistency of prosecution policy to protect them. I want to pick up two interesting aspects of the Dutch experience that are of particular relevance to England and Wales since the Purdy decision. The first is the way in which the changes in the basis of the decision to prosecute came to define the scope of legality. This happened in two ways.

First, in the strictly practical sense of when doctors would be likely to be prosecuted. A doctor considering whether they were exposing themselves to personal risk would have needed to look not at the primary legal principles but the prosecution practice. This could be said to be an example of divergence between the law as set out in the books and the practical realities of its implementation. Performing euthanasia remained a risk, as it was illegal, but that risk could be calculated more and more precisely as prosecution policy became more firmly established and codified. This was not a process that developed without regard for the law, as the prosecution policy was a reflection on the implications of court decisions on the scope of a statutory defence of necessity. ${ }^{23}$ It was, however, one driven outside of the legislature.

This is an important context for the litigation strategy pursued by Ms Purdy, but the approach was subtly different to hers. The focus in the Dutch system remained the position of the health professionals rather than that of the patient. This is significant both in respect of the analysis of the human rights convention and also in the guidance issued by the Director of Public Prosecutions in 2010. The perspective from which certainty over the legal position was judged in Holland was not that of the patient, nor that of her relatives (as raised by the Purdy litigation). Rather, it was that of the health professionals.

\footnotetext{
${ }^{22}$ See J Griffiths, A Bood \& H Weyers, Euthanasia and Law in the Netherlands (Amsterdam University Press 1998), pp 62-63.

${ }^{23}$ Under Article 40 of the Dutch Criminal Code.
} 
This was a key aspect of the transition towards the Dutch legalization of euthanasia. Indeed, the dominant characteristic of that reform can be said to be medicalisation rather than legalization. Even the definition given by the Dutch Supreme Court to the doctrine of necessity relied heavily on the views of the medical profession. ${ }^{24}$ This is a significant point, to which we need to return, in determining who controls the dying process.

\section{An inevitable end to the history of euthanasia?}

There is also a chronological perspective to be considered - the transition from pragmatic discretion in individual cases into a generalisable legal rule. Although the proper conclusions to be drawn from the Dutch evidence are much contested, it does seem clear that the practice has become normalized. The operation of the law in practice became its substance. This is sometimes described by those who oppose it as a classic example of the slippery slope - a slide from an apparently humane relaxation to accommodate personal tragedies into the routine and wholesale betrayal of fundamental moral values. Equally, proponents of the liberalization of euthanasia laws sometimes portray their programme of reform as an inevitable legal evolution from repression to freedom.

However, it is clear that such a slippery slope is not inevitable. Nor is the success of the project of legal relaxation guaranteed. First, it is possible to turn back on the slope. In 1995, the Australian Northern Territories passed the Rights of the Terminally Ill Act creating a right for patients die. It was not absolute, but it did provide a degree of control to those who met a set of criteria. They needed to be in the course of a terminal illness. They had to be experiencing pain, suffering and/or distress to an extent that was unacceptable to them. They could then request their doctor to assist them to end their life. On receipt of such a request, with the support of a second medical opinion and subject to a whole range of conditions, the doctor was permitted (but not obliged - note the medical gatekeeping) to assist in ending the patient's life. ${ }^{25}$ The liberalization of the law was, however, shortlived. Following an unsuccessful legal challenge to the competence of the Northern Territories to pass the legislation, ${ }^{26}$ the Act was overturned by the Federal Legislature which intervened to remove the competence of the states to legislate to permit euthanasia. ${ }^{27}$ Private members still seek to restore the Northern Territories legislation, but there seems no current prospect of success. ${ }^{28}$ The main point for the current argument is that this shows that reform can be undone and 'liberalisation' is not a one way street. However, it also shows how legal interventions that are apparently based on constitutional arguments mask deeper moral and political conflicts. ${ }^{29}$

\footnotetext{
${ }^{24}$ Griffiths et al note that the court referred specifically to the 'applicable norms of medical ethics' in determining the scope of 'necessity'. See p 63.

${ }^{25}$ The relevant materials can be found at http://www.nt.gov.au/lant/parliament/committees/rotti/parldebate.shtml (last accessed 22 October 2010).

${ }^{26}$ Wake and Gondarra v. Northern Territory and Asche [1996] NTSC 56.

${ }^{27}$ Euthanasia Laws Act 1997, No 17, 1997.

${ }^{28}$ See the Rights of the Terminally Ill (Euthanasia Laws Repeal) Bill 2008.

${ }^{29}$ Norrie's analysis of the criminal law makes a similar point about the application of orthodox criminal law doctrines hiding a particular ideology drawn from individualism, via the defence of private property
} 
It can also be shown that there is no necessary snowballing effect that leads inevitably to an avalanche of legislation once the first step is taken by one sister jurisdiction. In the USA, the Oregon Death with Dignity Act has now been in force for over 10 years. It is reported that 460 people have died within its scope, an estimated rate of 19.3 per 10,000 deaths for $2009 .{ }^{30}$ However, the legislation has not led to a domino effect across America. Although Washington passed legislation in similar terms in 2008, attempts to introduce bills in other states show little sign of success despite campaigners' enthusiastic claims. ${ }^{31}$ Similarly in Europe, euthanasia laws remain the exception rather than the norm. ${ }^{32}$ The suggestion that there is a steady 'progressive' movement towards legalization of assisted suicide is therefore unconvincing. It remains a matter of debate and properly within compass of deliberation in the world's legislatures. A drift towards euthanasia is not inevitable, but a matter of choice for societies. We might expect this choice to be exercised through the democratic processes designed to make our laws, but there are good reasons to be concerned that lawyers and doctors may be interfering with this exercise in democratic decision making.

\section{Lawyers and legislators}

A second and more immediately pressing question raised by the Dutch experience concerns the legitimacy of changing the substantive rules through decisions of professional bodies and state prosecutors rather than through Parliament. This seems inappropriate in a democratic society. In respect of the prosecutors, it should be noted that state prosecutors are part of the executive arm of government. If they make the law, rather than apply it, then the doctrine of the separation of powers between legislature, courts and government is compromised. Substantive change is supposed to be a matter for Parliament, not prosecutors.

The involvement of professional norms involves a separate problem for the rule of law. The Dutch could be said to have permitted the medical profession to rewrite the prohibition on euthanasia partly because doctors had concluded that medical ethics permits it, even though it was precluded by the law. Put starkly, the profession to be regulated could be said to have determined the scope of its own licence to kill. If the position taken by the profession is to be regarded as determinative, then perhaps English law should continue to reject assisted suicide so long as that remains the position of the BMA, but be nudged into change if that same bodied voted to support reform. This proposition seems perverse and an abdication of legislative responsibility. Medical ethics in such important matters is legitimately the wider concern of the state, and should be subject to the law not above it. This is, of course, a significant challenge for existing

and the liberal political philosophy of the utilitarians. See the concluding chapter to, Crime, Reason and History: a critical introduction to criminal law

${ }^{30}$ See the reports on the operation of the legislation http://www.oregon.gov/DHS/ph/pas/ar-index.shtml (last accessed 22 October 2010).

${ }^{31}$ E.g. http://www.deathwithdignity.org/2009/06/16/death-dignity-around-us/ (last accessed 22 October 2010)

32 J Griffiths, H Weyers, M Adams Euthanasia and Law in Europe (Oxford: Hart 2008). 
English law because of its tendency to incorporate professional standards as outlined above. $^{33}$

These concerns were brought into sharp relief by the juxtaposition of the two events in the House of Lords in July 2009. The legislative House rejected a provision proposing to exclude from the scope of the criminal offence of assisting suicide those who helped a terminally ill adult travel abroad by 194 votes against to 141 in favour. The focus of the amendment was on those who have travelled to Switzerland, where assisted suicide is permissible even without the need to establish a prior connection with the country. This was the same focus as in the Purdy case, as it was to Switzerland that she planned to travel. Many of the arguments however, were as applicable to offences committed in England as the overseas context was not essential to them, and of course in both cases the prosecution would be under the Suicide Act 1961, passed when suicide was decriminalized (but not necessarily approved by the law). ${ }^{34}$ Many of the arguments were also familiar from the wider debates around euthanasia: sympathy for those in extremis; concern about the values being expressed by the proposed reform, particularly about the vulnerable and disabled; difficulties in the interpretation of the draft legislation; respect for the autonomy of those dying.

However, these arguments were generally framed in a different way from the account of the clash of values that was articulated by the European Court of Human Rights in Pretty $v$ UK, decided in 2002. ${ }^{35}$ Here, the court accepted a model based on competing rights. It held that Article 8 of the Convention protected an individual's right to exercise autonomy in the manner of their dying, but that this was limited by the need to respect the rights and freedoms of others. Prohibiting assistance in suicide was justified in order to protect vulnerable people from pressure to end their lives prematurely. This way of characterizing the legal question - a clash of individual legal rights - makes it more difficult for arguments based on human dignity and the fundamental value of life to succeed. The shift of paradigm from the debate about competing values to one about the impact of positions (based on such values) on specific and (in principle identifiable) individuals may fundamentally alter the nature of the legal debate.

If the authority to legislate against euthanasia and assisted suicide depends on this balancing, then it will increasingly turn on empirical questions. Can it be demonstrated that the Suicide Act's prohibition of assistance does in fact provide protection? Can this evidence show that the interference in individual freedoms is proportionate to the protection provided? These are hard things to prove. In Pretty, the Court accepted the UK state's claim that the prohibition of assisted suicide served to protect vulnerable people's rights. It did not consider empirical evidence to that effect. This is not likely to be sufficient for ever, as the example of recognition of transsexuals demonstrates. There, the European Court of Human Rights lost patience with the delay in increasing that recognition and moved (on quite limited evidence), from a view that variety was

\footnotetext{
${ }^{33}$ See also José Miola, 'Medical Law and Medical Ethics - Complementary or corrosive?' (2004) 6 Medical Law International 251-274 and the extended argument in his Medical Ethics and Medical Law (Hart, 2007). For a different emphasis, see J Montgomery, 'Law and the demoralisation of medicine' (2006) 26 Legal Studies 185-210.

${ }^{34}$ This general overlap of issues makes it unsurprising that the DPP felt unable to limit either the interim or final prosecution policy to cases where the death occurred abroad, although it should be noted that Lewis, op.cit. note 4 takes a different view on this point.

${ }^{35}$ [2002] 2 FCR 97.
} 
permitted to states as laws gradually evolved, to the position that sufficient uniformity across Europe had been established to require the UK to act. ${ }^{36}$ The formulation of the test set out in Pretty could, in fact, be said to stack the cards against those who resist liberalization, fettering the discretion of legislators to determine how the issues should be defined. It could also be seen as a legally imposed constraint on democratic decision making in an area where there is little consensus on the fundamental issues that have been raised. Arguably, this need to preserve a margin of appreciation in the democratic process, under the shadow of the human rights convention but not dictated by its legal formulations, was the basis on which the judicial committee of the House of Lords preferred to hold that Diane Pretty's right to respect for private and family life was not engaged by the prohibition of the assisted suicide. ${ }^{37}$

In Purdy, however, a different legalistic dimension has emerged, in the form of an argument about the value of legal certainty and the ability of people to assess the risk of prosecution. Even more starkly than in Pretty, argument has shifted from substance to form. The new element of the discussion over the amendment in the House of Lords and set out in the decision in Purdy concerns not the substance of the rules but the ability of people to plan how to work with them. It is a deceptively simple proposition. It is said that in Pretty, the European Court of Human Rights established that the desire of citizens to exercise control over the manner of their dying was legally legitimate. The fact that this right was limited did not exclude its fundamental existence and validity.

Consequently, the argument goes, if people have such a right, then they should be able to plan how to exercise it, otherwise they could not 'regulate' their behaviour to stay within the law. The next step is to argue that because some people have used the opportunity of travelling to Switzerland to pursue that legitimate right without prosecution they must somehow have acted within the law. If they have done so, the argument goes on, it is only fair that everyone else must be able to assess the risk of prosecution and plan accordingly.

In the legislative House of Lords, the legislators were invited to create a defence to the prohibition on assisted suicide that had been crafted to regularise this practice of travelling abroad to utilize the opportunities afforded under Swiss law. They declined the invitation. The Judicial Committee of the House of Lords was less timid. Their lordships built out of Article 8 an argument requiring the Director of Public Prosecutions to do something very close to what their legislative colleagues had declined to do. Before turning to the detail, it is important to note that this argument relies upon at least two unacknowledged steps, each of whose logic can be challenged.

First, the people who are assessing the risk of being prosecuted are not the same people on whose claim to privacy the argument rests. There is no privacy right to end someone else's life, only a right to autonomy over one's own dying. The argument began with Ms Purdy's Article 8 rights not those of her husband. However, it is not her behaviour but that of her husband which it is now claimed cannot be properly regulated because of the vagueness of the law. The legality of such behaviour may be seen as ancillary to the exercise of Mrs Purdy's right, but it is not itself the exercise of a Convention right. In the absence of positive obligations on the state to facilitate suicide,

\footnotetext{
${ }^{36}$ Goodwin v UK [2002] 2 FCR 577; I v UK [2002] 2 FCR 613.

${ }^{37}$ R(Pretty) v DPP [2002]1 All ER 1.
} 
denied in Haas $v$ Switzerland, ${ }^{38}$ it is not necessary to extend the scope of the claim to legal certainty in the way the House of Lords chose to do. Such an extension needs specific explanation and justification, which was not offered in the case.

The second subtle but significant shift concerns the difference between the legal rule and the process of policing it. It is not generally thought that the validity of a rule imposing a defined speed limit on a road is uncertain because traffic cameras have been turned off in some parts of the country, so that the chance of being caught and prosecuted is reduced and unpredictable. The reasoning in Purdy suggests that in the euthanasia context the position is somewhat different. It suggested that the probability of prosecution was as relevant to the required legal certainty as the content of the rule prohibiting the criminal behaviour. $^{39}$

\section{Purdy v DPP - the need for precision}

This ability to plan ahead was, therefore, the key issue in the Purdy litigation. Pretty had concerned the balance of competing rights set out in Article 8 of the European Convention on Human Rights, and whether it satisfied the requirements of proportionality. The Purdy decision focused on the requirement under that article which requires that any restrictions on fundamental freedoms should be 'in accordance with the law'. It interpreted that phrase as requiring a clarity and precision of process that leads us to think about what we mean by the concept of 'law' in this context. It suggests that it might not be sufficient that the wording of the statute is clear. Its formulations are suggested to be only part of what constitutes the 'law' that must be sufficiently precise? In addition, the practice of prosecutors needs to be similarly predictable and well defined before the human rights test is satisfied. In other words, the suggestion raised by the House of Lords in Purdy was that a clear statutory rule could be rendered non-compliant by an uncertain approach taken by the prosecutor.

This suggestion has some plausibility in relation to assisted suicide because the offence in question is controlled by an explicit need for prosecutorial permission, and thus the prosecution discretion can be said to be more constitutive of the 'law' than in the case of more general criminal provisions (although there will always be an element of prosecutorial discretion for all offences). Under the Suicide Act 1961, prosecutions can only be brought by the Director of Public Prosecutions. ${ }^{40}$ Considering this, the House of Lords held that the Director had failed to give sufficient guidance on how he would consider the exercise of his discretion to satisfy the test of 'in accordance with the law'. It found that without further precision, the law was too vague to enable people to regulate their lives in order to stay within its requirements. As a consequence their human rights required greater clarity to be given.

\footnotetext{
${ }^{38}$ Affaire Haas c. Suisse Case no. 31322/07, judgement 20 January 2011, available only in French at the time of writing.

${ }^{39}$ In relation to the content of the rules themselves, it should be noted that offences can be sufficiently certain to satisfy the requirements of the ECHR even though they incorporate prevailing professional practice into their definition; see $R v$ Misra, $R v$ Srivastava [2004] EWCA Crim 2375 (concerning gross negligence manslaughter in the medical context).

${ }^{40} \mathrm{~S} 2$ (4). This subsection was not affected by the codification of the substantive provision into more modern legal language under the Coroners and Justice Act 2009.
} 
If the issue were merely about process and not about substance, then no great concern would be raised about requiring the Director of Public Prosecution to promulgate further guidance. The decision appears to be about the requirement for precision of the prosecutor's approach in advance of events, not about whether actions are banned or permitted. However, it has in fact forced the Director to sail very close to the wind in avoiding trespassing into the territory properly reserved to legislators rather than law officers. Once the steps previously taken by the DPP are taken into account, the issues cannot plausibly be said to be about either the transparency or accountability of the law officers, both of which might be reasonable grounds for criticism if they could be made out. If the reasons for individual decisions are unclear, then it would not be possible to assure the public that they are taken fairly, consistently and in a non-discriminatory manner. However, it would be wholly unfair to criticize the Director of Public Prosecution for being secretive about his approach. Indeed, due to his commitment to openness, more was known about the approach taken to prosecution decisions in the context of assisted suicide by the time of the Purdy case than ever before and certainly more than could have been ascertained when the European Court of Human Rights had accepted the conformity of the UK law against assisted suicide in the Pretty case.

\section{Prosecution guidelines before Purdy}

In December 2008, the Director had taken the bold step of setting out the basis for his decision not to prosecute the parents of Daniel James, after they accompanied him to Switzerland in order to end his life in premises operated by the organization Dignitas. ${ }^{41}$ Daniel was 23 years old at the time of his death. Eighteen months before, he had sustained a serious spinal injury in a rugby accident that left him tetraplegic: paralysed from the chest down and with no independent hand or finger movement. Prior to travelling to Switzerland he had made several attempts to end his own life as he 'could not envisage a worthwhile future for himself.' His parents tried relentlessly to dissuade him, but came to accept his wish to travel. They assisted him to make the arrangements in a number of respects that the Director or Public Prosecutions concluded would have passed the evidential test for prosecutions. They had assisted him to send documentation to the Swiss organization. They had made payments to it from their joint bank account. They had made the travel arrangements to take him there and they had accompanied him on the flight. Although the parents did not assist in the act of suicide itself, the DPP concluded that there was a 'realistic prospect of conviction' under the Code for Crown Prosecutors, so that a prosecution should usually take place 'unless there are public interest factors tending against prosecution which clearly outweigh those tending in favour. ${ }^{42}$

The decision to prosecute therefore turned on the issue of public interest. This is dangerous territory for codification. The prosecutor cannot be seen to be undermining the

\footnotetext{
${ }^{41}$ Keir Starmer QC, Director of Public Prosecutions, 'Decision on Prosecution - The Death by Suicide of Daniel James (9 December 2008, http://www.cps.gov.uk/news/articles/death_by_suicide_of_daniel_james/index.html, last accessed 25 October 2010)

${ }^{42}$ Code for Crown Prosecutors, para 5.7.
} 
law - that would be to usurp the legislative function. Public interest considerations cannot therefore contradict the policy behind the law by determining that the prohibited actions are in fact acceptable, only that in the particular circumstances of the case the policy behind the criminal prohibition can be upheld without visiting the normal consequences upon the perpetrator.

In the Daniel James decision, the Director of Public Prosecutions stated that he had considered the factors identified in the Code and concluded that very few pointed in favour of prosecution. The main one that did was the seriousness of the offence, involving the loss of a life and carrying a maximum penalty of 14 years imprisonment. However, the force of this factor was considerably reduced by the Director's assessment that a court would have been very unlikely to impose a custodial penalty and that in all probability the sentence would be either an absolute discharge or a small fine.

This conclusion seems entirely reasonable given the practice of the courts in socalled 'mercy killing' cases. When the House of Lords' Select Committee on Medical Ethics, considered the issues in 1993, it was told that prosecutions were rare. In the period 1982 to 1991 (inclusive) the police coded only twenty-four homicide cases as mercy killings. ${ }^{43}$ In most of them, the alleged killers were close relative of the deceased. No proceedings were taken in three of these cases. Two prosecutions that were brought resulted in acquittals. There were sixteen convictions for manslaughter and only one for murder. ${ }^{44}$ Messages on the seriousness with which the offences were regarded were also given through sentencing. Only three of the convicted killers went to prison (although two received suspended prison sentences). Most were put on probation (twelve). One case resulted in a conditional discharge.

The Director went on to note that the parents were in a position of trust and markedly older than their son, factors that the code indicated would usually point towards prosecution. However, these were offset by his intelligence and independence so that he was not open to manipulation by them. He also considered that prosecution was not likely to have a significant positive effect on community confidence, and that this was not therefore a factor pointing to prosecution on the facts of the case. Other factors that were thought to be significant were that the parents did not influence Daniel's decision to commit suicide, but had sought to dissuade him; his full capacity to take the decision; his previous suicide attempts; and the fact that the parents did not stand to make financial gain.

In the light of this detailed account, it might have been thought that the DPP had gone a considerable way to clarify his approach to prosecutions. By June 2009, at least 115 people were known to have travelled from the UK in similar circumstances. From these, 8 cases (including the James case) had been referred to the DPP for consideration. Although the detailed reasons have not been made public, in six of the cases a decision not to prosecute was taken on the ground of insufficient evidence, so that no public interest judgment needed to be made. In one case, there was a decision that a prosecution was not taken because of public interest factors, but without the reasons being made public. As we have seen, in the case of Daniel James a full account of the reasons was

\footnotetext{
${ }^{43}$ Oral Evidence, HL Paper (1993-4), 28-II, 18, 25.

${ }^{44}$ In one case there was an infanticide conviction and in the remaining case, the suspect died before proceedings were concluded.
} 
issued. ${ }^{45}$ Lest the lack of prosecution in these cases be taken to suggest that the law has fallen into disuse, it should be noted that the CPS commenced criminal proceedings in 16 instances of alleged assisted suicide within the jurisdiction between April 2005 and September 2009. ${ }^{46}$ Thus, it is clear that the law is not being ignored, and that the DPP has tried to explain the approach taken, at least to cases with an international element.

\section{Post-Purdy - the search for compliance}

Following the ruling in Purdy, an interim policy was issued, which also served as a consultation document on whether the policy would win public confidence. ${ }^{47}$ A number of aspects of this consultation deserve consideration. First, the extent to which it offered greater clarity than could already be deduced from the publication of reasons in the Daniel James case. Unless it did, then it seems unlikely that the requirements of the decision in the House of Lords will have been met. Second, whether this search for greater clarity has led the DPP to trespass into legislative territory, raising the concerns about the separation of powers identified earlier. Finally, how the conclusion of this skirmish in the battle over dying might seem to the main antagonists.

The interim guidance expressly required consideration of the provisions of the general code, applied in the James decision. In addition, factors that were identified as pointing towards or against prosecution covered three broad categories. Characteristics of the victim that might make prosecution more likely were said to be young age (under the age of eighteen) or impaired capacity, absence of a serious health problem from which recovery is impossible (terminal illness, severe degenerative condition or severe and incurable disability), and ability to perform the acts constituting the assistance themselves. Factors relating to the decision included whether there was a clear, settled and informed wish to commit suicide and whether that was likely to change. Factors relating to the assistant included close relationship, wholly compassionate motivation, lack of any persuasion or coercion, and lack of financial benefit. Prosecution would be less likely in these circumstances and more likely if they are absent.

Pro-euthanasia campaigners welcomed the Purdy decision as a vindication of their position. However, they may have been less content with the terms of the interim guidance. It is hard to see what it contained that could not already have been deduced from the terms of the James decision. There were, however, some aspects that it might have taken as steps towards reframing the legislation in the manner of the Dutch reforms. It can be argued that the interim policy implied that assisted suicide would be condoned provided that the victim had an incurable health problem, had formed a settled intention to commit suicide and that there was no evidence of improper motive. If this was sustained, then it seems that, at the behest of the House of Lords, the Director had trodden where Parliament chose to leave alone. As with Pretty, but to a rather more explicit degree, the Purdy decision could therefore be said to impair the democratic processes by compromising the traditional separation of powers.

${ }^{45} R$ (Purdy) v DPP [2009] UKHL 45, Para 30.

${ }^{46}$ CPS, 'Key Facts - Assisted Suicide Interim Policy', September 2009, http://www.cps.gov.uk/consultations/as_keyfacts.html (last accessed 25 October 2010).

${ }^{47}$ For detailed discussion of the drafting of interim and final policies, see P Lewis, op cit n 4. 
Despite its flaws, ${ }^{48}$ the consultation attracted considerable interest. Nearly 5,000 responses were received, over 1,000 of which expressed concern at the DPP stepping into territory that was the proper province of Parliament. ${ }^{49}$ The revised guidelines can be seen to have made a number of key changes that reflect this concern. The most significant of these are the removal of health conditions from the list of relevant factors and the antipathy to organized activities to support assisted dying, especially where health professionals are involved. Penney Lewis has shown how these changes raise awkward policy questions, many of which have been addressed in the overseas jurisdictions that have developed laws to permit physician assisted suicide. ${ }^{50}$ However, this may address the wrong questions. Although Lewis notes the Director's avowed intent to avoid creating a regulatory regime for assisted suicide, she neglects to explore further the implications of this position.

The focus in the interim policy on the health condition of victim had the effect of recasting issues around assistance in suicide as questions about the assistance of euthanasia. The distinctions being made in these two cases are different. Suicide is to be distinguished from homicide - self-killing rather than killing of another. Consequently, the key issues concern the principal actor, whether it is the deceased taking their own life or a third party taking the life of another. Provided it is the former, then cases look like suicide rather than homicide and attention turns to ensuring that there was a free choice to end their lives. In contrast, euthanasia concerns the distinction between a good and a bad death. Consequently, the nature of the death and any alternatives that may be available to the possible deceased are significant, because only in their light can an assessment be made of the relative attractions. Here, issues such as the curability of the health conditions or the availability of palliation are relevant. So too is the policy objective of ensuring that once a decision for death is made, the most effective and dignified steps are taken to implement that decision.

Penney Lewis criticises the Director's policy as seeming to be 'designed to ensure that assistance in suicide remains an amateur activity carried out by inexperienced individuals. ${ }^{51}$ The force of that criticism comes from the assumption that the context is distinguishing poor deaths from good deaths - the euthanasia paradigm. If, however, the context is distinguishing suicide from homicide, the force of this criticism is weakened. In this context, the key questions are about the decisions of the deceased, not the manner of the dying, and the policy would not be expected to address the broader questions. The focus on the clarity of the decision taken by the deceased, and the identification of factors relevant to the presence of direct or indirect pressure, seem to explain the changes between the interim and final policy. An examination of the first few public decisions on the implementation of the new prosecution policy also confirms this understanding of what the Director has set out to achieve.

\footnotetext{
${ }^{48}$ Explored by $\mathrm{P}$ Lewis, op cit $\mathrm{n} 4$.

49 Public Consultation Exercise on the Interim Policy for Prosecutors in respect of Cases of Assisted Suicide Issued by The Director of Public Prosecutions. Summary of Responses at http://www.cps.gov.uk/consultations/as_responses.html (last accessed 30 October 2010)

${ }^{50}$ Explored by P Lewis, op cit $\mathrm{n} 4$.

${ }^{51}$ This is the formulation quoted by Patricia Hewittt in the House of Commons, 10 March 2010 (Col 403) and is slightly longer than the similar phrase in op cit n 4 at p 10 .
} 


\section{Clarity in practice?}

In the first six months following the publication of the prosecution guidance, three public explanations were given of decisions, which in each case were that prosecution would not be in the public interest. Little can be gleaned from the decision not to press charges following the death of Caroline Loder. ${ }^{52}$ The statement of reasons merely indicates that in respect of one of those brought to the attention of the police, 'some advice' was given to an 83 year old woman who 'plainly intended to commit suicide' and that there was no evidence that this advice had contributed significantly to the outcome. In those circumstances, although the giving of the advice had been said to be 'itself sufficient evidence to provide a realistic prospect of conviction', the public interest did not require prosecution. The other person involved was said to have given help 'of a practical nature contributing only to the preparations that the deceased made.' It was clear that he acted out of compassion in order to respect Mrs Loder's wishes. Again, prosecution was not required by the public interest.

The case of Sir Edward and Lady Downes was perhaps more typical of the scenarios envisaged by Mrs Purdy when she brought her case. The famous conductor and his wife had made use of the services of the Swiss Dignitas organization. Their children had accompanied them, with their son having assisted in the making of travel arrangements. The Director of Public Prosecutions concluded that the public interest did not require the prosecution of the son, despite the fact he had concluded that there was sufficient evidence to mean that there was a realistic prospect of securing a conviction. The actions that would have founded such a prosecution were the booking of a hotel room for his parents' use before attending the Dignitas Clinic and accompanying them on their flight to Switzerland. The fact that these were actions that the deceased couple had been able to undertake for themselves, constituted a factor that pointed in favour of prosecution. However, as they were of only minor assistance and it was clear that his parents had reached a voluntary, clear, settled and informed decision to commit suicide pointed against prosecution. So too was the openness of the accused, in that he had reported his parents' suicide to the police, through his solicitor, and had fully assisted in their enquiries.

The most interesting aspect of the Downes decision concerns the analysis of the son's motivation, given that he stood to inherit under his parents' will. It should be noted that his sister would also have inherited, but in relation to her, the DPP found there was no evidence that she took any action in England that could have assisted her parents, so that that there was no evidence on which a prosecution could have been brought. The prosecution policy indicates that only where the motive was 'wholly compassion' would there be a factor suggesting that prosecution was not in the public interest. ${ }^{53}$ However, it also noted that where compassion was the 'only driving force', then the fact that some benefit may be gained from the death should not usually require prosecution. ${ }^{54}$ That was the conclusion reached in the Downes case.

\footnotetext{
52 'No charges following death of Caroline Loder', CPS press statement, 16 August 2010.

${ }^{53}$ See para 43.f and 45.b. For discussion of this element of the guidance, see A Mullock, 'Overlooking the criminally compassionate: what are the implications of prosecutorial policy on encouraging or assisting suicide?' (2010) 18 Med Law Rev 442-470.

${ }^{54}$ Para 44.
} 
The third published decision concerned the death of Mr Raymond Cutkelvin in February 2007, but which only came to light following an article in the London Evening Standard over two years later. It drew attention in part because of the involvement of Dr Michael Irwin, a former GP who had been struck off the medical register and was well known for his membership of Dignitas and his strong views that the law on assisted suicide was in need of liberalization. Dr Irwin had contacted Mr Cutkelvin when asked to do so by Dignitas and had paid £1,500 from his own funds towards the costs of the assisted suicide. He travelled with the deceased to Switzerland. Taken together, these facts, which Dr Irwin knew aided Mr Cutkelvin to commit suicide, mean that the DPP concluded that there was a realistic prospect of conviction. Again, therefore, it was necessary to consider whether the public interest required prosecution.

It might have been thought that there were significant factors in favour of prosecution within the published policy. Dr Irwin had been previously unknown to the deceased and had approached him rather than responded to his enquiry. He had previously been involved with other people using the services of Dignitas and had been cautioned for possessing a fatal dose of barbiturates that he intended to supply to a doctor friend. Thus, he had a previous history of offending that was relevant to the public interest decision under the general Code for Crown Prosecutors. He was motivated by a strong belief that the law on assisted suicide was wrong. The DPP noted that it could therefore be argued that he was not wholly motivated by compassion, but found that he did in fact feel sorry for the deceased and his civil partner. He described this as a mixed motive. He placed some weight on the fact that there was no prospect of personal gain as Dr Irwin was not acting as an employee of Dignitas.

Despite these factors pointing in favour of prosecution, the Director concluded that it would not be appropriate to bring proceedings. The overwhelming consideration was that Mr Cutkelvin had reached a voluntary, clear, settled and informed choice to commit suicide as a 'strong minded man' without any pressure from Dr Irwin. Prior to any contact with the doctor he had resolved not to be treated for the pancreatic cancer with which he had been diagnosed and had drawn up a living will to ensure that his wishes in this respect were respected. He had contacted Dignitas independently and the subsequent approach from Dr Irwin was the result of Mr Cutkelvin's initiative. Had a conviction resulted, the Director envisaged that the likely sentence would be a conditional discharge (given the three year delay since the suicide, the doctor's age (at 79 years) and the fact that the 'victim' would have committed suicide even if Dr Irwin had not assisted, in addition to the factors around notice already discussed).

A similar conclusion was reached in relation to Mr Alan Rees, the deceased's civil partner. Again, there was sufficient evidence for there to be a realistic prospect of conviction. Mr Rees had collated the information required by Dignitas, used their joint money to find the trip to Switzerland, and accompanied his partner when he travelled. While these were said to be to the 'remote end of the spectrum' as acts capable of constituting assistance in a suicide, given the clear intention to aid the deceased, the evidential test was passed. Mr Rees had also discussed Mr Cutkelvin's decision and supported it, but the Director concluded that in the absence of acts of active encouragement this would 'rarely, if ever, be capable' of being an offence.

These reports of the Director's conclusions are of course heavily dependent on the circumstances of the case and therefore cannot be accorded precedential status in the way 
that a judicial explanation of the law can be taken as a fairly strong guide to future practice. Nevertheless, they do suggest that in cases where the parties fully co-operated with the police (as in all of these), the Director will be reluctant to progress to prosecution provided that the deceased is shown to have reached an free, informed and settled decision to commit suicide. In none of the cases did the Director consider the nature of the health conditions facing the deceased in any detail. In the Loder and Downes cases, his explanation for his decision not to prosecute contained nothing at all about their reasons for choosing to die or their health status. This was despite media reports suggesting that while Lady Downes had been diagnosed as terminally ill, Sir Edward was suffering disabilities but was not close to death. In the context of the debate over euthanasia, those different health conditions might be thought to raise different considerations. The distinctions are not, however, relevant if the only issue is whether the deceased truly and freely determined to commit suicide. In the Cutkelvin decision, the medical diagnosis was identified, but only as the context in which the deceased's resolve to die had been consistently expressed and was therefore indirect evidence that neither his partner nor Dr Irwin had not persuaded him to commit suicide. ${ }^{55}$

In this way, as with the revisions to the interim policy, the Director has managed to divert attention away from the question of the motivation of the deceased (and the question of what sort of death was sought, which quickly engages the broader question of the duel over death) into the distinction between suicide and homicide. Thus, in his prosecution decisions as well as the drafting of the policy under which they are taken, he has successfully walked the front line between the warring factions without being drawn to either camp. It seems, therefore, that to criticize the prosecution policy for been a poor framework for regulating euthanasia is to ask a different question from the one the Director attempted to answer.

Of great interest, however, is the way in which each of the decisions had concluded that the evidential hurdle for prosecution was so easily made out. In none of the cases summarized in this section was there any participation in the suicide itself. In relation to the Swiss cases, this was in part because only activities undertaken in England were considered relevant. Nevertheless, the actions considered to pass the evidential threshold concerned preparation and support in making plans, not assistance in the act of dying. This may be taken to suggest that the scope of the actions that fall within the scope of the offence of assisting suicide may be far broader than some have previously thought. This is a matter which will be addressed shortly in the context of the requirement of clarity identified in the Purdy decision. Before then, it is necessary to consider the response of Parliament to the Director's attempts to clarify the position.

\section{Democracy barks back?}

Parliament has not remained silent during the period in which the Director of Public Prosecutions has grappled with task required of him by the judicial House of Lords in Purdy. Its discussions reflect many of the themes that have already been drawn

\footnotetext{
${ }^{55}$ See para 5 where the diagnosis is mentioned as inoperable (without other treatment options being discussed), and paras 6,39 and 46(b) where his decision to make a living will refusing life sustaining treatment is noted but the medical condition itself is not referred to.
} 
out in this account of the skirmish between the antagonists in the duel over control over death and dying. Parliament has both explored the constitutional implications of the decision in the case and also demonstrated the inconclusive and protracted nature of the war being fought.

An early day motion in the House of Commons, opened by Ann Widdecombe MP, attracted 70 signatories to a criticism of the attack on Parliamentary supremacy that she perceived the interim guidelines to involve. ${ }^{56}$ The text read

That this House notes the judgement of the Law Lords in the appeal of Debbie Purdy requiring that the Director of Public Prosecutions (DPP) publish guidelines for those contemplating assisting another to commit suicide; further notes that in following the Law Lords, the DPP has produced a document informing people what to do to avoid prosecution; further notes that the DPP, like the Law Lords, states clearly that it is the function of Parliament, not the judiciary to make and amend legislation; considers that the guidelines override the will of Parliament; recalls that twice recently the House of Lords has rejected by a clear majority attempts to change the law on assisted suicide, the second time in July 2009 when a clause to introduce assisted suicide through the Coroners and Justice Bill was defeated by 191 votes to 141; further notes the comment of Lord Carlile of Berriew QC, a foremost human rights lawyer, that before prosecution for theft or grievous bodily harm, 'we are not told how much we can steal...or how much injury we can inflict...'; further notes that through indicating to would-be offenders how best to avoid prosecution, the DPP will put the vulnerable at grave risk; and calls on the Government to require the withdrawal of the guidelines, leaving Parliament rather than the judiciary or unelected civil servants to consider whether to change the law, and making it clear to the judiciary that they are not permitted to override the supremacy of Parliament.

Although, as is usual with such motions there was no debate, the relatively large number of signatories indicates recognition of a real issue. Whether this level of support reflected views on the constitutional issue that was raised, or whether signatories saw it as an opportunity to record opposition to the perceived liberalization of the law is unclear. The motion conflated the two and appears to have been introduced as a tactic to resist a perceived slide towards euthanasia.

The House of Commons did briefly discuss the issues in an adjournment debate on 11 March $2010 .{ }^{57}$ Here a very different intention seems to have motivated the proposer from that behind the early day motion. Former Secretary of State for Health, Patricia Hewitt raised a number of concerns about the differences between the consultation document and the final policy. These included the removal of the reference to terminal illness or serious degenerative illness and the also increased risk introduced by the final guidelines for health professionals involved in assistance. She proposed a royal commission to look into the issues, expressing confidence that 'it is no longer a question of whether the law will change but a question of when it will change.' To her, it was clear that while the new guidelines 'distinguish between compassionate assistance

\footnotetext{
${ }^{56}$ EDM 302, introduced 1 December 2009.

${ }^{57}$ Hansard, 10 March 2010, Col 401ff.
} 
given to someone who has reached "a voluntary, clear, settled and informed decision to commit suicide" and malicious, irresponsible or organised help', they were not the end of the matter. For her, this was merely a step on the path towards a liberalization of the law that she supported.

The Parliamentary Under-Secretary of State for Justice responded 'that any change in the law is an issue of individual conscience, and is rightly a matter for Parliament rather than Government policy to decide. The Government therefore take a neutral view when others seek to change the law, which means that we, as the Government, should neither stand in the way of such a change nor actively pursue it.' The Minister downplayed the significance of the guidelines, saying that it was not the case that the DPP was 'doing anything now that he was not doing before the policy for prosecutors was published.' Thus, she neutralized the affront to Parliamentary supremacy towards which the DPP had been pushed by the judicial House of Lords while deferring the euthanasia questions to another time and (in the light of the impending general election) another Parliament.

In the House of Lords, another former Health Minister, Lord Warner, described the task given to the Director as a 'poisoned chalice', describing the current legal regulation of euthanasia as 'the nudge and a wink approach to putting you out of your misery - very British'. ${ }^{58}$ Like Patricia Hewitt, he argued for an independent inquiry into the issues. The main additional argument to those already explored in the earlier debates concerned the role and current state of public opinion. He used the results of the British Social Attitudes Survey 2010 (where 82\% expressed support for assisted dying) as an argument for further investigation. Others were less convinced. Some because the issues were already clear and it was not necessary to hold an enquiry, merely to take a decision (including eminent lawyers on both sides of the substantive question, see the speeches of Lord Goodhart and Baroness Butler-Sloss, formerly President of the Family Division).

These debates demonstrate that the duel over death remains a lively contest best seen as part of the long running campaign. This sense of re-engagement in the battle was expressed by many of those resisting further debate. Lord Bach, for the Government, rejected the call for a public inquiry saying

'the very fact of setting up such an inquiry would be seen by some as tantamount to a policy decision that the law should be changed. In the debate, it was interesting that those in favour of change were very keen on an inquiry and those who were against change were equally keen for there not to be one. ${ }^{59}$

The Bishop of Durham likened it to 'the old business of holding the referendum again and again until people give the right answer' and suggested that 'Parliament is there not to bend to every media-manipulated public whim, but to take the larger and longer view. ${ }^{60}$ It is clear that there is considerable scope for democratic debate over the issues and that opinions remain divided. Parliament has sought to mark out the issues as within its own jurisdiction, not that of the courts or the state prosecutor, precisely as might be expected given the orthodox analysis of the separation of powers.

\footnotetext{
${ }^{58}$ Hansard, House of Lords, 3 February 2010, Col GC69.

${ }^{59} \mathrm{Col} \mathrm{GC} 80$.

${ }^{60}$ Col GC72. See also Lord Carlile at GC74.
} 


\section{Judicial bite? What significance for the Purdy ruling?}

It has been argued that it is unwise to assess the significance of the Director's new policy on the assumption that it is a step on a particular path towards the regulation of assisted dying. The final policy is better presented as an attempt to avoid being drawn into the substantive debate. It is more an inconclusive distraction or minor skirmish in the perennial duel over the control of death and dying than a victory for either side. This raises a question as to whether the issued policy could be said to neutralize the Purdy ruling and therefore be vulnerable to the same grounds for challenge as were raised in that case.

Perhaps the problem lies in seeing section 2(4) of the Suicide Act 1961 - the requirement of the Director's oversight - as a substantive provision, defining the offence, rather than a procedural protection against its heavy handed use. From the points of view of Diane Pretty and Debbie Purdy, the opinions of the Director of Public Prosecutions were crucial to their assessment of what their husbands could safely do to assist them. The situations in which the discretion to prosecute would be exercised therefore seemed to define the behaviour criminalized by the Act. Their expectations were perhaps coloured by the Dutch experience, whereby clarity on the likelihood of prosecution developed into an effective immunity for those who complied with the agreed processes (and some would argue also for many who did not).

If clarity of this type is required to satisfy the human rights standard for restrictions being 'in accordance with the law', and if this is what the House of Lords has required the Director of Public Prosecutions to produce, then the judges have precipitated a constitutional tension between the arms of the state. For they have required the DPP to elaborate on his prosecution policy to such an extent as to change the basis of the criminal offence. At any time, this raises questions about the authority of prosecutors to legislate to make they law what they desire it to be, not what it actually is. To suggest that the DPP does that within two weeks of Parliament actually deciding not to change the law in the direction proposed raised the stakes even further.

However, it is possible to see the restriction of prosecutions to cases where the Director consents as a restriction against heavy handed prosecutions by those who feel strongly about the issues at stake and might seek to force a prosecution in order to use the law as part of the duel over death and dying rather than to police the risk of exploitation of the individual who has died. ${ }^{61}$ From this perspective, the basis for the prosecution discretion is not constitutive of the terms of the offence, but an application of the quality of mercy. The law is clear - anybody who assists in a suicide is liable to prosecution. ${ }^{62}$ That could be said to be the level at which clarity is required to meet the 'in accordance with the law' test. It operates not in that part of prosecutorial discretion concerned with the public interest test, but with the evidential requirement. There needs to be clarity

\footnotetext{
${ }^{61}$ See by way of comparison the Jepson litigation where a Church of England curate sought to force a prosecution for a fetal abnormality abortion; Jepson v Chief Constable of West Mercia [2003] EWHC 3318 (QB) .

${ }^{62}$ See Lord Hope in Purdy at para 27.
} 
about the actions that constitute the offence, measured by the evidence of its commission, to enable people to regulate their conduct as required by human rights law. Yet as the Director's account of his decisions makes clear, this is comparatively easy to explain and is broadly defined. If the policy behind the prohibition is to proscribe assistance in suicide, then it is already clear what sort of assistance will be found to have come within the scope of the offence. Anybody contemplating becoming involved in an act of selfeuthanasia can identify what will make them liable to prosecution and can regulate their behaviour accordingly. Should they 'commit' the offence, they may appeal to mercy from the prosecutor or later from the courts. Here, they are entitled to expect that decisions will be consistent rather than arbitrary, but they are raising questions relating to the public interest in enforcing the law, not seeking a dispensation from the rules prohibiting the acts. Creating such a dispensation, or immunity, would be to undermine the policy of the law. That is a matter for Parliament.

\section{Conclusion}

I have argued that the outcome of the duel over 'deliverance in death' is not inevitable and that we therefore need to continue to seek a careful account of the bases and limits of legislative, judicial and executive authority in the development of the law. I have suggested that this may be a more fruitful way of unraveling the complexities of the current debates than a focus on the titanic clash between individual autonomy and human dignity.

John Donne, with whose sermon I began this lecture, is perhaps better known for the words of his seventeenth Devotion, in which he wrote 'No man is an Island, entire of itself... Therefore do not send to ask for whom the bell tolls, it tolls for thee.' He stressed the importance of recognizing the ways in which human lives are interconnected. We cannot treat individual deaths as solely a matter for the deceased. Pretty was therefore right to recognize that the personal interests of the person contemplating death are not the only consideration. The rights and freedoms of others may be affected.

However, we should be wary of legalistic solutions that force us to a simplistic view of the nature of the problems faced in connection with the dying. Donne's point was that the death of another spurs us to contemplate our own mortality, not that it should dictate the conclusion of that contemplation. To accept as Pretty did, the need to prohibit assisted suicide in the interests of others, on the basis of assertion rather than evidence, probably lets supporters of the status quo off too lightly. But to limit the evidence to that of direct harm rather than moral debate would be to take away from legislatures their proper role of resolving important controversies. The broader point concerns the problems created by over-reliance on the structures of law (when developed for purposes other than the regulation of dying) and the vagaries of test-case litigation.

I have suggested that we should distinguish carefully the roles of legislators in defining the rules, judges in interpreting them, and prosecutors in determining whether to invoke them. The trap opened up by the decision in Purdy lies in the blurring of the functions. It seems to have pushed the Director of Prosecution into the role of legislator, and arguably to have usurped aspects of that role itself. This is understandable in the 
absence of legislative consideration but highly problematic when the legislator had considered it only weeks before and declined to change the law. In the event, the Director has skillfully negotiated a path that clarifies his prosecution policy without stepping into legislative territory. However, the preservation of the constitutional niceties remains precarious given the continuing controversy.

Each of the roles - legislation, adjudication and prosecution - has a place for lawyers but they are different. The contribution of the law to the debate over death and dying should focus on the opportunity that the differentiation of roles gives for a more sophisticated analysis of the regulatory options than the simplistic binary question of either banning or permitting assisted suicide. The type of amendment considered by the House of Lords in July, or the provisions of the overseas legislation we have briefly considered may indeed be appropriate reforms of the law. However, they deserve full democratic debate and the conclusions reached by legislators should be respected not undermined by the courts. Lawyers can assist in the drafting of these rules but they have no privileged place above other professionals and members of the public in the determining the policy that they implement.

The particular skills of lawyers can be deployed in this way to enable a transition between the conflict of 'death's duel' into a more civilized collaboration in which we work together to build a society in which we can express our commitment to human dignity and rights in a way that does not force specific individuals to carry a high personal cost to secure a thinly spread benefit for others. The recognition that dying is not merely a personal issue is not a justification for removing all control from the individual. As a social institution, the law can handle this in a number of ways, but at present, in England, it is through entrusting the enforcement of the law to the Director of Public Prosecutions. This enables the finessing of the fundamental legal problem of how to do specific justice through the medium of generalized rules. That way we can both express our commitment to the value of life while recognizing that it is sometimes harsh to impose that view on people who do not see it in their own lives.

To do that, we need to accept that a demonstration of fairness and justice is required to establish that the balancing of these values is in accordance with the law. But this is to be achieved not by requiring a law officer to turn legislator but in accountability in administration. Decisions must be transparent and open, but prosecutorial discretion, enabling justice to be tempered with mercy, may actually be a better guarantee than the skills of parliamentary drafters or the wisdom of judges dealing with test cases. In summary, in the context of assisted suicide, the gates of St Peter are guarded by the Director of Public Prosecutions. We should be very wary of tinkering with the constitutional settlement by which the keys are placed in his hands. 